\title{
PENGETAHUAN KADER KESEHATAN DALAM PENDAMPINGAN IBU HAMIL UNTUK PERSIAPAN PERSALINAN
}

\author{
Titi Astuti ${ }^{1}$, Aprina $^{2 *}$, Al Murhan ${ }^{3}$ \\ 1,2,3 Jurusan keperawatan politeknik kesehatan tanjungkarang, \\ Email Korespondensi: Aprinamurhan@yahoo.co.id \\ Disubmit: 27 Desember 2021 Diterima: 31 Desember $2021 \quad$ Diterbitkan: 02 Januari 2022 \\ DOI: https://doi.org/10.33024/jkpm.v1i1.5694
}

\begin{abstract}
ABSTRAK
Puskesmas yang cakupan K4 masih rendah yaitu Puskesmas Hajimena yaitu $89,1 \%$. Hasil wawancara pengabdi dengan kader Kesehatan di desa Hajimena dari 45 kader Kesehatan tugas mereka adalah membantu penimbangan bayi dan balita diposyandu, belum terpapar peran yang lain yaitu membantu ibu hamil dengan mendeteksi kehamilan normal, berisiko dan persiapan pendampingan ibu saat akan bersalin. Kegiatan ini dilaksanakan di Masjid Ulul Albab Desa Hajimena. Tujuan Kegiatan ini untuk memberikan Pengetahuan ibu kader Kesehatan dalam pemahaman kehamilan normal dan risiko, persalinan normal dan risiko serta pendampingan kader pada ibu hamil mempersiapkan persalinannya, sangat membantu ibu ibu hamil yang berada dilingkungan sekitarnya. Kegiatan pengabmas ini dilaksanakan oleh 3 Tim yang merupakan dosen kelompok keilmuan keperawatan maternitas dan anak dan kelompok Kesehatan masyarakat, dan tim juga telah berpengalaman menjadi ketua atau anggota tim dalam penelitian-penelitian sebelumnya dijurusan keperawatan poltekkes tanjungkarang. pada Jurusan Keperawatan Poltekkes Tanjungkarang dengan melibatkan 4 orang mahasiswa, Setekah dilakukan penyampaian materi dan implementasi peran kader,menunjukkan peningkatan dari sebelum diberikan materi oleh tim pengabmas dan sesudah diberikan materi oleh tim, dan hal ini menunjukkan peran kader dalam persiapan persalinan sangat mendukung tercapainya perawatan antenatal terhadap ibu hamil dalam mempersiapkan persalinannya untuk mencegah terjadinya resiko pada ibu hamil sebelum dan sesudah persalinan.
\end{abstract}

Kata Kunci: Pengetahuan Kader, Ibu Hamil, Persalinan

\begin{abstract}
Puskesmas with low K4 coverage is Hajimena Health Center, which is $89.1 \%$. The results of interviews with health cadres in Hajimena village from 45 health cadres, their job is to help weigh babies and toddlers at the posyandu, not yet exposed to other roles, namely helping pregnant women by detecting normal, risky pregnancies and preparing for maternal assistance when giving birth. This activity was carried out at the Ulul Albab Mosque, Hajimena Village. This community service activity was carried out by 3 teams who were lecturers of the maternity and child nursing scientific group and the public health group, and the team also had experience as chairpersons or team members in previous studies in the nursing department of the Tanjungkarang Health Polytechnic. at the Department of Nursing at the Tanjungkarang Health Polytechnic involving 4
\end{abstract}


students. After the delivery of material and implementation of the role of cadres, it showed an increase from before being given material by the community service team and after being given material by the team, and this shows the role of cadres in preparation for childbirth is very supportive of achieving antenatal care to pregnant women in preparing for childbirth to prevent risks to pregnant women before and after delivery.

Keywords: Cadre Knowledge, Pregnant Women, Childbirth

\section{PENDAHULUAN}

Ada peningkatan kesadaran global bahwa perawatan berkualitas baik adalah kunci untuk menjaga ibu dan bayi tetap hidup dan sehat. Saat ini, setiap tahun ada 303.000 kematian wanita selama kehamilan dan persalinan, 2,6 juta kelahiran mati, dan 2,7 juta kematian bayi selama 28 hari pertama kehidupan. Antara 1990 dan 2015, kematian ibu di seluruh dunia turun sekitar 44\%. Antara 2016 dan 2030, sebagai bagian dari Sustainable Development Goals (SDGs), targetnya adalah untuk mengurangi rasio kematian ibu melahirkan global menjadi kurang dari 70 per 100.000 kelahiran hidup. Perawatan yang lebih baik dapat mencegah banyak dari kematian ini. (WHO, 2017).

Angka Kematian Ibu (AKI) di Indonesia masih tinggi, pada tahun 2012 berjumlah 359/100.000 kelahiran hidup dan pada tahun 2015 berjumlah 305/100.000 kelahiran hidup. Usaha percepatan penurunan AKI di Indonesia dilakukan dengan menjamin agar setiap ibu mampu mengakses pelayanan kesehatan ibu yang berkualitas, seperti pelayanan kesehatan ibu hamil, pertolongan persalinan oleh tenaga kesehatan terlatih di fasilitas pelayanan kesehatan, perawatan pasca persalinan bagi ibu dan bayi, perawatan khusus dan rujukan jika terjadi komplikasi, kemudahan mendapatkan cuti hamil/melahirkan dan pelayanan keluarga berencana. (Profil Kesehatan Indonesia, 2017).

Pemerintah sudah menjalankan upaya perbaikan dengan berbagai program seperti ANC terpadu, kelompok Ante Natal, program perencanaan persalinan dan pencegahan komplikasi (P4K), Desa Siaga dan program lainnya, namun beberapa indikator data masih menunjukkan adanya masalah. Berdasarkan data Profil Kesehatan Indonesia tahun 2017, cakupan kunjungan kehamilan (K4) di Indonesia mencapai 86,57 \% sedangkan data persalinan oleh tenaga kesehatan di fasilitas kesehatan baru mencapai 83,14\%, jadi masih ada selisih yang cukup besar sejumlah 3,43\%. Data di Lampung, cakupan K4 mencapai 91,31 \% dan data persalinan oleh tenaga kesehatan di fasilitas kesehatan baru mencapai 90,1 \%, jadi masih ada selisih sejumlah 1,21\%. Data selisih ini menggambarkan masih adanya persalinan yang tidak ditolong oleh tenaga kesehatan.Padahal data puskesmas yang melaksanaan kelompok Ante Natal di Indonesia sudah 92,71\% dan program P4K sudah mencapai 89,24\%. Di Lampung Tengah kedua program ini bahkan dinyatakan sudah mencapai target. (Profil Kesehatan Indonesia, 2017).

Sedangkan di Kabupaten Lampung Selatan masih termasuk rendah bila dibandingkan dengan kabupaten lainnya seperti Kabupaten Tanggamus, Kota Bandar Lampung, Kabupaten Pringsewu dan Kota Metro,dan tahun sebelumnya termasuk dalam 7 Kabupaten dengan Cakupan K4 terendah di provinsi Lampung (Profil Dinkes Provinsi Lampung, 2015). Berdasarkan data profil Kesehatan Kabupaten Lampung Selatan tahun 2018 cakupan K4 sebesar

93\% (21.731 ibu hamil), mengalami peningkatan dari tahun sebelumnya 92,96\% (21.508 ibu hamil). Hal tersebut berarti masih dibawah target SPM yang 
ditentukan sebesar 100\%. Puskesmas yang cakupan K4 terendah adalah Puskesmas Hajimena yaitu $89,1 \%$. Hasil pre survey yang dilakukan oleh Aprina dan Titi astuti kepada ibu hamil di wilayah kerja puskesmas Hajimena hampir sebagian besar wanita usia subur di wilayah kerja Puskesmas ini masih ada yang belum mengetahui manfaat dari pentingnya melakukan kunjungan antenatal care. Selain itu hampir sebagian besar wanita usia subur diwilayah Puskesmas Hajimena adalah ibu rumah tangga yang tidak bekerja dengan latar belakang pendidikan menengah kebawah. Demikian pula dengan dukungan kader kesehatan dalam menyampaikan informasi mengenai kehamilan dan pentingnya melakukan jadwal kunjungan yang sesuai jadwal masih cukup kurang.

Hasil penelitian yang dilakukan oleh Titi Astuti dan Abdul Halim dari analisis statstistik Pengaruh Kader dalam pendampingan persiapan persalinan pada ibu hamil sangat diperlukan untuk mencegah terjadinya resiko pada ibu hamil sebelum dan sesudah persalinan, perubahan prilaku ibu hamil juga berpengaruh terhadap kesiapan dalam persalinannya, oleh sebab itu penelitian ini menjelaskan bahwa hasil pengaruh pendampingan kader pada ibu hamil sangat signifikan untuk persiapan persalinan ibu hamil tersebut.

Tim pengabdi berupaya membantu kader Kesehatan meningkatkan pengetahuan dan ketrampilan kader dalam mengenal kehamilan yang normal dan risiko, mengenalkan persalinan normal dan risiko dan peran kader dimasyarakat bisa sigap membantu ibu hamil mempersiapkan apa saja yang harus dibawah saat persalinan . Usulan kegiatan Peningkatan Peran pendampingan kader terhadap persiapan persalinan ibu hamil dimana dalam perawat antenatal care yang didampingi kader akan memberikan untuk mencegah terjadinya resiko pada ibu hamil sebelum dan sesudah persalinan, perubahan prilaku ibu hamil juga berpengaruh terhadap kesiapan dalam persalinannya. Saat melakukan penerapan pendampingan kader tim pengabmas sebelumnya akan memberikan penerapan kepada para kader dalam perawatan antenatal terhadap ibu hamil dalam mempersiapkan persalinannya. Adapun sasaran kegiatan ini ada seluruh kader kesehatan serta tim kesehatan yang terdapat di wilayah kerja puskesmas Hajimena. Kegiatan ini akan dilaksanakan di posyandu Bataranila dalam waktu selama 10 bulan dengan target sasaran sebanyak 45 kader kesehatan .

Kegiatan ini diharapkan sepenuhnya dapat dibiayai oleh DIPA Poltekkse Tanjungkarang, dan akan dilaksanakan oleh tim yang terdiri dari 3 orang dosen yang memiliki kemampuan penyuluhan dibidang Kesehatan Reproduksi dan kemampuan pelatihan kepada tim kesehatan serta kader untuk menggunakan penerapan pendampingan kader dan manfaat yang diterima. Tim akan didukung juga oleh 4 orang mahasiswa yang terdiri dari 2 orang mahasiswa semester IV Prodi DIV dan dua orang mahasiswa semester IV Prodi DIII Keperawatan Tanjungkarang yang sudah dilibatkan pada saat penelitian dilaksanakan. Kegiatan diharapkan dapat terlaksana dengan baik dengan dukungan bahan dan peralatan yang diperlukan untuk kegiatan penyuluhan dan pelatihan tersebut.Rencana kegiatan penyuluhan dan pelatihan peningkatan pengetahuan kader Kesehatan dilakukan saat pandemik Covid 19, dalam pelaksanaan tetap menggunakan Protokol Kesehatan , sehingga Kader Kesehatan dapat mengikuti pembelajaran dengan tertib dan terjaga kesehatannya.

Hasil wawancara pengabdi disaat kegiatan posyandu ,kader Kesehatan terdapat 5 kader disetiap posyandu dan ada 9 posyandu dengan jumlah kader 45 orang di desa Hajimena.Pada bulan Maret 2021 dari 15 kader yang ditanyakan mengenai kehamilan dan persiapan yang bisa kader lakukan saat ibu hamil menghadapi persalinan, $95 \%$ belum mengetahui peran kader Kesehatan dalam 
pendampingan ibu hamil dalam persiapan persalinan. Selama ini ibu kader melakukan kegiatan penimbangan bayi dan balita,pemberian vitamin A dan bila adan ibu hamil disuruh datang ke Posyandu. Sebagai ketua kader posyandu , sangat merespon kegiatan untuk menambah pengetahuan anggota sehingga akan memudahkan pelaksanaan program pengabmas yang akan dilaksanakan.

Tujuan Kegiatan ini untuk memberikan Pengetahuan ibu kader Kesehatan dalam pemahaman kehamilan normal dan risiko, persalinan normal dan risiko serta pendampingan kader pada ibu hamil mempersiapkan persalinannya, sangat membantu ibu ibu hamil yang berada dilingkungan sekitarnya.

\section{MASALAH}

kondisi mitra dapat diambil permasalahannya mitra antara lain :

a. Hasil wawancara dengan petugas Puskesmas yang cakupan K4 masih 89,1\% Diperlukan peran kader dalam mengajak ibu hamil kunjungan untuk melakukan pemeriksaan kehamilan di Puskesmas maupun di Posyandu.selama ini kegiatan kader di posyandu membantu penimbangan bayi dan balita,utk ibu hamil hanya menyarankan datang ke Posyandu.

b. Hasil wawancara pengabdi disaat kegiatan posyandu ,kader Kesehatan terdapat 5 kader disetiap posyandu dan ada 9 posyandu dengan jumlah kader 25 orang di Desa Hajimena.Pada bulan Maret 2021 dari 15 kader yang ditanyakan mengenai kehamilan dan persiapan yang bisa kader lakukan saat ibu hamil menghadapi persalinan, $95 \%$ belum mengetahui peran kader Kesehatan dalam pendampingan ibu hamil dan persiapan persalinan.

c. Hasil wawancara dengan ketua kader dan kader Kesehatan di Desa hajimena ,belum memahami tugas kader pada pendampingan ibu hamil dalam persiapan persalinan.

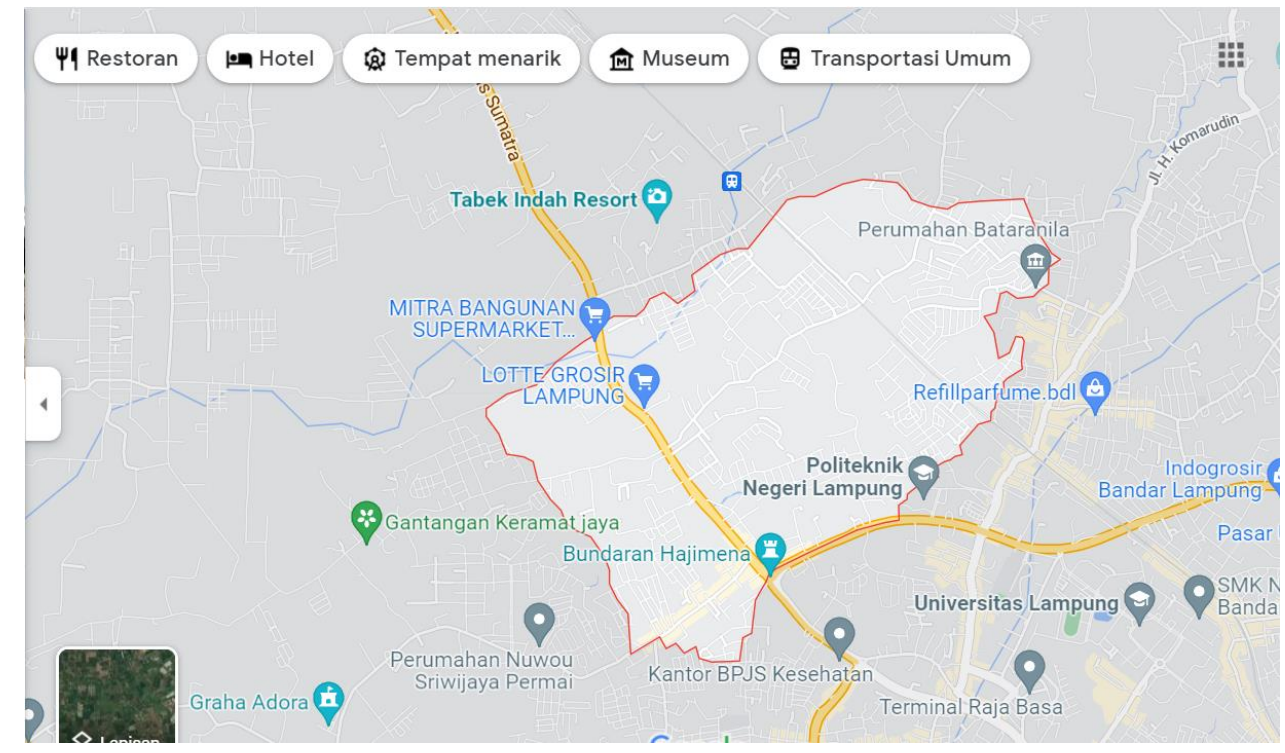

Gambar Peta Lokasi Kegaiatan Pengabdian Kepada Masyarakat 


\section{METODE PELAKSANAAN}

a. Tahap Persiapan

1) Penentuan Sasaran dengan kegiatan : Menentukan kriterian sasaran atau mitra pengabmas, Memilih sasaran sesuai kriteria dan menetapkan sasaran

2) Penjajakan dan perizinan dengan kegiatan Melakukan penjajagan ke lokasi, mengidentifikasi masalah mitra, Menyepakati persetujuan sasaran , Mengurus izin kegiatan

3) Pembuatan proposal kegiatan : Menyusun proposal untuk di sleksi, merevisi proposal dan mendapatkan ketetapan proposal terpilih

4) Sosialisai program dengan kegiatan menjelaskan program yang akan di laksanakan pada mitra dan menyepakati program

b. Pelaksanaan

1) Koordinasi tim di lakukan sebelum kegiatan pengabmas langsung ke lapangan meliputi pembagian tugas tim, persiapan alat bahan sesuai kebutuhan kegiatan

2) Sebelum pelaksanaan dilakukan memastikan semua persiapan siap d gunakan dan memastikam tim dan peserta siap memulai kegiatan

3) Pelaksanaan kegiatan di sesuaikan dengan bertahap agar tujuan bisa tercapai

Adapun kegiatan rinci sebagai berikut :

1) Kegiatan 1 : Penjelasan tentang kehamilan normal dan risiko

Sasaran : Kelompok Kader Kesehatan berjumlah 25 kader Kesehatan

Waktu : minggu ke 1 juni 2021

Tempat : Posyandu (sesuai kesepakatan)

Tim : Ns. Titi Astuti,M.Kep;Sp.Mat (pemateri)

Dr. Aprina ,S.Kp,M.Kes (pemateri)

Al Murhan, SKM;M.Kes ( Moderator)

Mahasiswa ( Fasilitator)

Metode : Pre tes tentang kehamilan normal dan risiko

Penyampaian Materi

Diskusi dan tanya jawab

Post tes

Evaluasi : score tes pengetahuan $>60 \%$ diatas $50 \%$ peserta

2) Kegiatan 2 : Penjelasan tentang Persalinan normal dan risiko

Sasaran : Kelompok Kader Kesehatan berjumlah 25 kader Kesehatan

Waktu : minggu ke 1 juni 2021

Tempat : Posyandu (sesuai kesepakatan)

Tim : Ns. Titi Astuti,M.Kep;Sp.Mat (pemateri)

Dr. Aprina ,S.Kp,M.Kes (pemateri)

Al Murhan, SKM;M.Kes ( Moderator)

Mahasiswa ( Fasilitator)

Metode : Pre tes tentang Persalinan normal dan risiko

Penyampaian Materi

Diskusi dan tanya jawab

Post tes

Evaluasi : skore tes pengetahuan $>60 \%$ diatas $50 \%$ peserta

3) Kegiatan 3 : Penjelasan tentang Persalinan aman dan nyaman

Sasaran : Kelompok Kader Kesehatan berjumlah 25 kader Kesehatan

Waktu : minggu ke 1 juni 2021

Tempat : Posyandu (sesuai kesepakatan)

Tim : Ns. Titi Astuti,M.Kep;Sp.Mat (pemateri) 


\section{Dr. Aprina ,S.Kp,M.Kes (pemateri) \\ Al Murhan, SKM;M.Kes ( Moderator) \\ Mahasiswa ( Fasilitator)}

Metode : Pre tes tentang Persalinan aman dan nyaman

Penyampaian Materi

Diskusi dan tanya jawab

Post tes

Evaluasi : skore tes pengetahuan $>60 \%$ diatas $50 \%$ peserta

4) Kegiatan 4 : Penjelasan tentang Persiapan Persalinan

Sasaran : Kelompok Kader Kesehatan berjumlah 25 kader Kesehatan

Waktu : minggu ke 2 Juni 2021

Tempat : Posyandu (sesuai kesepakatan)

Tim : Ns. Titi Astuti,M.Kep;Sp.Mat (pemateri)

Dr. Aprina ,S.Kp,M.Kes (pemateri)

Al Murhan, SKM;M.Kes ( Moderator)

Mahasiswa ( Fasilitator)

Metode : Pre tes tentang Persiapan Persalinan

Penyampaian Materi

Diskusi dan tanya jawab

Post tes

Evaluasi : skore tes pengetahuan $>60 \%$ diatas $50 \%$ peserta

5) Kegiatan 5 : Penjelasan tentang Peran kader dalam persiapan kehamilan

Sasaran : Kelompok Kader Kesehatan berjumlah 25 kader Kesehatan

Waktu : minggu ke 2 Juni 2021

Tempat : Posyandu (sesuai kesepakatan)

Tim : Ns. Titi Astuti,M.Kep;Sp.Mat (pemateri)

Dr. Aprina ,S.Kp,M.Kes (pemateri)

Al Murhan, SKM;M.Kes ( Moderator)

Mahasiswa ( Fasilitator)

Metode : Pre tes tentang Peran kader dalam persiapan kehamilan

Penyampaian Materi

Diskusi dan tanya jawab

Post tes

Evaluasi : skore tes pengetahuan $>60 \%$ diatas $50 \%$ peserta

6) Kegiatan 6 : Penjelasan tentang Peran kader dalam persiapan persalinan

Sasaran : Kelompok Kader Kesehatan berjumlah 25 kader Kesehatan

Waktu : minggu ke 3 Juni 2021

Tempat : Posyandu (sesuai kesepakatan)

Tim : Ns. Titi Astuti,M.Kep;Sp.Mat (pemateri)

Dr. Aprina ,S.Kp,M.Kes (pemateri)

Al Murhan, SKM;M.Kes ( Moderator)

Mahasiswa ( Fasilitator)

Metode :Pre tes tentang Peran kader dalam persiapan persalinan

Penyampaian Materi

Diskusi dan tanya jawab

Post tes

Evaluasi : skore tes pengetahuan $>60 \%$ diatas $50 \%$ peserta

7) Kegiatan $7:$ Implementasi pendampingan kader pada ibu hamil dalam mempersiapkan persalinan

Sasaran : Kelompok Kader Kesehatan berjumlah 25 kader Kesehatan 
Waktu : minggu ke 3 Juni 2021

Tempat : Posyandu (sesuai kesepakatan)

Tim : Ns. Titi Astuti,M.Kep;Sp.Mat (pemateri)

Dr. Aprina ,S.Kp,M.Kes (pemateri)

Al Murhan, SKM;M.Kes ( Moderator)

Mahasiswa ( Fasilitator)

Metode : Pre tes Pendamping kader dalam persiapan persalinan

Penyampaian Materi

Diskusi dan tanya jawab

Post tes

Evaluasi : skore tes pengetahuan $>60 \%$ diatas $50 \%$ peserta.

\section{c. Monitoring Dan Evaluasi}

1) Monitoring dengan memantau setiap kegiatan sesuai rencana dan di laksanakan selama peroses pengabmas dengan mofikasi kegiatan sesuai tujuan

2) Evaluasi dengan melakuan evaluasi pada tahap akhir kegiatan pengabmas :

Kegiatan 8 : Implementasi tentang Peran kader dalam persiapan persalinan

Sasaran : Kelompok Kader Kesehatan berjumlah 25 kader Kesehatan

Waktu : minggu ke 3 Juni 2021

Tempat : Posyandu (sesuai kesepakatan)

Tim : Ns. Titi Astuti,M.Kep;Sp.Mat (pemateri)

Dr. Aprina ,S.Kp,M.Kes (pemateri)

Al Murhan, SKM;M.Kes ( Moderator)

Mahasiswa ( Fasilitator)

Metode :Pre tes tentang Peran kader dalam persiapan persalinan

Penyampaian Materi

Diskusi dan tanya jawab

Post tes

Evaluasi : skore tes pengetahuan $>60 \%$ diatas $50 \%$ peserta.

\section{d. Tahap Akhir}

Pada tahap akhir keseluruhan kegiatan pengabmas dengan pengumpulan dokumen kegiatan, penyusunan laporan dan revisi laporan, penggandaan laporan, pengumpulan laporan serta penyusunan artikel pengabmas dan publikasi hasil pengabmas 


\section{HASIL DAN LUARAN YANG DICAPAI}

Kegiatan peran kader dalam pendampingan ibu hamil dan persiapan persalinan

a. Pre Test Pengetahuan Kader
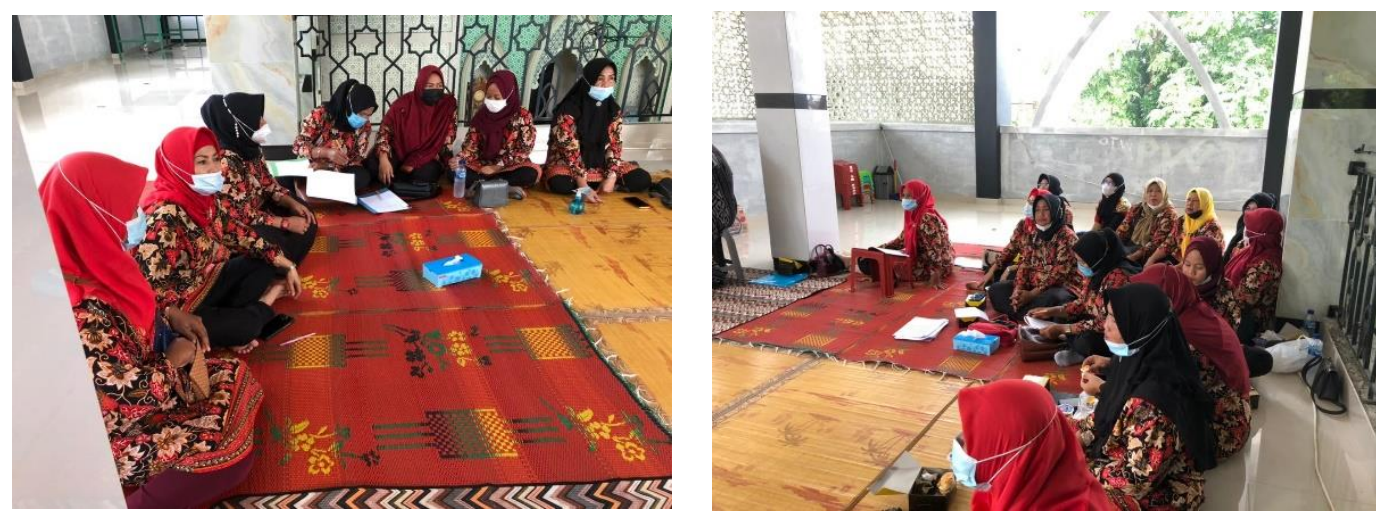

Gambar 1 Pre test kepada Kader

Tabel 1 Hasil Pre test kepada Pengetahuan Kader

\begin{tabular}{llcccc}
\hline \multirow{2}{*}{ No. } & Peserta Pengabmas & \multirow{N}{*}{} & \multicolumn{3}{c}{ Hasil Pre Test } \\
\cline { 3 - 6 } 1. & $\begin{array}{l}\text { Materi 1: kehamilan } \\
\text { normal dan risiko }\end{array}$ & 25 & 2 & 10 & 13 \\
\hline 2. & $\begin{array}{l}\text { Materi 2: Persalinan } \\
\text { normal dan risiko }\end{array}$ & 25 & & 15 & 10 \\
\hline 3. & $\begin{array}{l}\text { Materi 3: Persalinan } \\
\text { aman dan nyaman }\end{array}$ & 25 & & 12 & 13 \\
\hline 4. & $\begin{array}{l}\text { Materi 4: Peran kader } \\
\text { dalam persiapan } \\
\text { persalinan }\end{array}$ & 25 & 5 & 8 & 12 \\
\hline
\end{tabular}

Kegiatan Pre test ini dilaksanakan dengan tujuan merefleksi kemampuan kader mengenai pengetahuan kader dari mulai Materi 1: kehamilan normal dan risiko, Materi 2: Persalinan normal dan risiko, Materi 3: Persalinan aman dan nyaman dan Materi 4: Peran kader dalam persiapan persalinan, Masingmasing materi terdiri dari 10 pertanyaan sederhana, item penilaian dari pre test ini terdiri dari 3 kategori yaitu Baik, Cukup dan Kurang, hasil penilaian Baik jika peserta dapat menjawab 4-5 pertanyaan, hasil penilaian Cukup jika peserta dapat menjawab 3-2 pertanyaan, dan hasil penilaian Kurang jika peserta dapat menjawab 1 pertanyaan atau tidak mampu menjawab pertanyaan dengan baik, kegiatan ini diikuti oleh 25 Kader kesehatan di desa hajimena,

Hasil Pre Test yang didapatkan pada Materi 1: tentang kehamilan normal dan risiko, didapatkan pengetahuan kader Baik terdapat 2 (8\%), pengetahuan kader Cukup terdapat 10 (40\%) dan pengetahuan kader Kurang terdapat 13 (52\%).

Pada hasil pre test Materi 2 : tentang Persalinan normal, didapatkan pengetahuan kader Cukup terdapat 15 (60\%) dan pengetahuan kader Kurang terdapat 10 (40\%), sedangkan hasil pre test Materi 3: tentang Persalinan aman dan nyaman didapatkan pengetahuan kader Cukup terdapat 12 (48\%) dan pengetahuan kader Kurang terdapat 13 (52\%). 
Sementara pada hasil Pre test materi 4: yaitu tenta[ng Peran kader dalam persiapan persalinan didapatkan pengetahuan kader Baik terdapat 2 (8\%), pengetahuan kader Cukup terdapat 10 (40\%) dan pengetahuan kader Kurang terdapat $13(52 \%)$.

\section{b. Kegiatan Penyampaian Materi Kepada Kader}
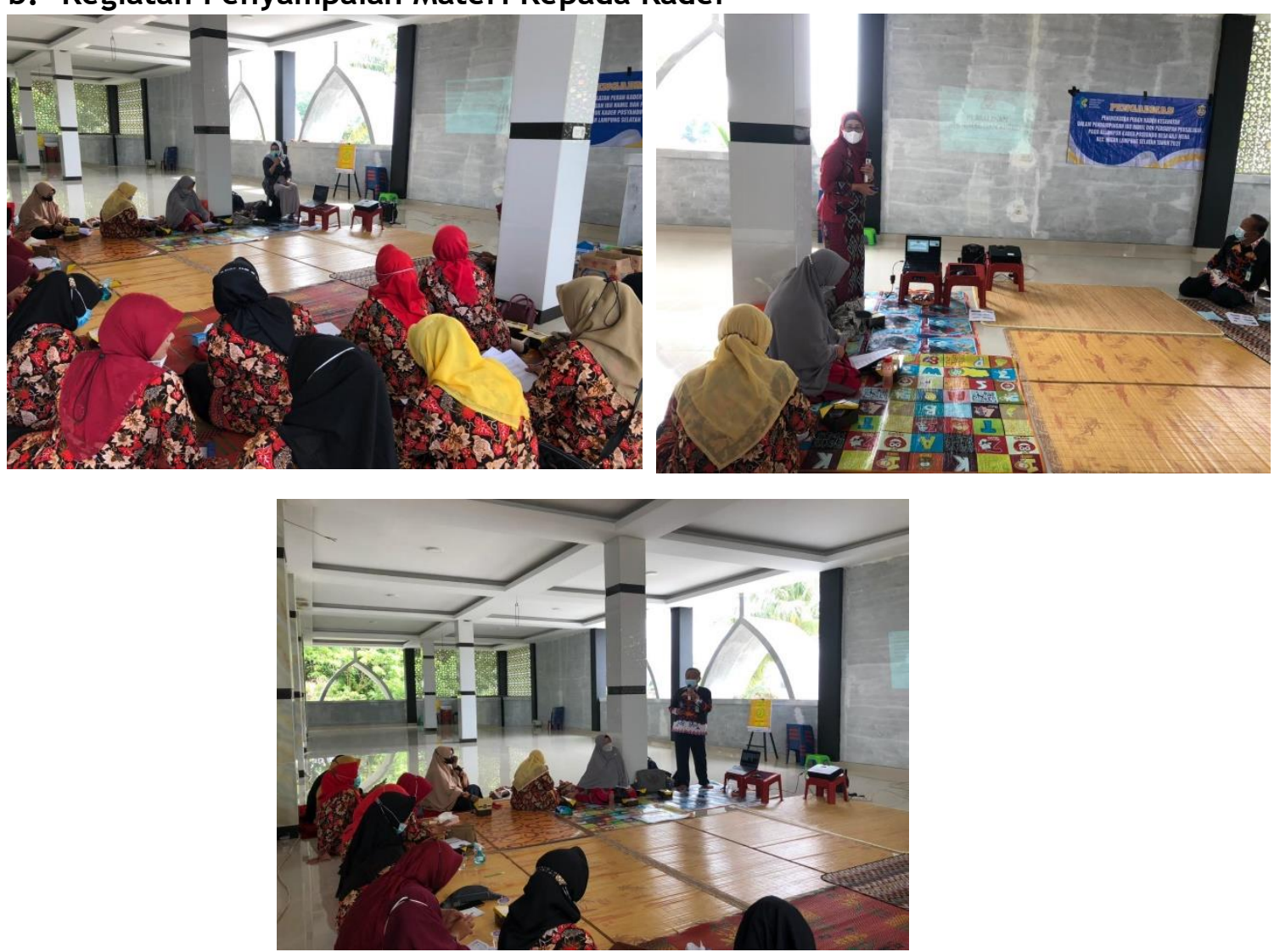

Gambar 2 Kegiatan Penyampaian materi

Kegiatan penyampaian materi diberikan kepada tim Pengabmas dan didampingi mahasiswa sebagai fasilitator dalam kegiatan pengabmas ini, penyampaian materi diberikan setelah peserta/ kader kesehatan mengikuti Pre test. Materi yang disampaikan berkaitan tentang peran kader dalam pendampingan ibu hamil dan persiapan persalinan.

Terdiri dari 4 (Empat) materi yang disampaikan diantaranya adalah: Materi 1: kehamilan normal dan risiko, Materi 2: Persalinan normal dan risiko, Materi 3: Persalinan aman dan nyaman dan Materi 4: Peran kader dalam persiapan persalinan, masing-masing materi disampaikan oleh Tim pengabmas dibagi sesuai bidang keilmuannya.

Hasil kegiatan penyampaian materi ini memberikan respon positif bagi Peserta Pengabmas/ kader kesehatan, dimana peserta pengabmas sangat antusias dalam menerima materi yang diberikan, selain itu banyak nya peserta ikut dalam diskusi dan mengajukan beberapa pertanyaan mengenai peran kader terus ditanyakan oleh peserta/ kader kesehatan.

Maka dapat di simpulkan kegiatan penyampaian materi ini memberikan dampak positif bagi kader kesehatan, dan memberikan pengetahuan kepada kader mengenai kehamilan, persalinan, dan apa saja yang harus diedukasikan oleh kader kepada ibu hamil mengenai persiapan persalinan dan pentingnya peran kader dalam mendampingi pesiapan dan persalinan ibu hamil. 


\section{c. Post Test Pengetahuan Kader}
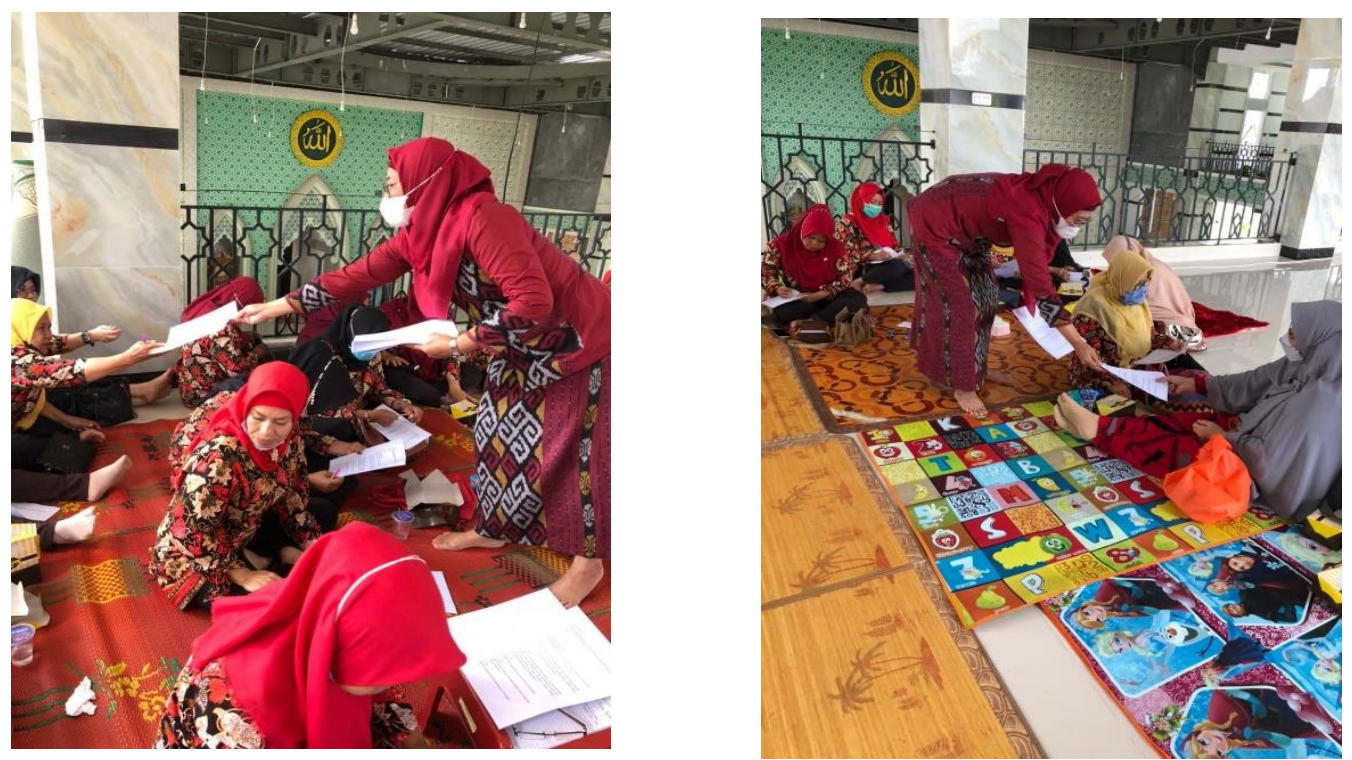

Gambar 3 Post test kepada Petugas Kesehatan dan Kader

Tabel 2 Hasil Post test kepada Pengetahuan Kader

\begin{tabular}{lllcl}
\hline \multirow{2}{*}{ No. } & Peserta Pengabmas & \multirow{N}{*}{} & \multicolumn{2}{c}{ Hasil Pre Test } \\
\cline { 4 - 4 } 5. & $\begin{array}{l}\text { Materi 1: kehamilan } \\
\text { normal dan risiko }\end{array}$ & 25 & Baik & Cukup Kurang \\
\hline 6. & $\begin{array}{l}\text { Materi 2: Persalinan } \\
\text { normal dan risiko }\end{array}$ & 25 & 25 \\
\hline 7. & $\begin{array}{l}\text { Materi 3: Persalinan } \\
\text { aman dan nyaman }\end{array}$ & 25 & 25 \\
\hline 8. & $\begin{array}{l}\text { Materi 4: Peran kader } \\
\text { dalam persiapan } \\
\text { persalinan }\end{array}$ & 25 & 25 \\
\hline
\end{tabular}

Setelah kegiatan penyampaian materi selanjutnya Kegiatan Post test yang dilaksanakan dengan tujuan mengeveluasi pengetahuan kader setelah diberikan materi oleh tim pengabmas, materi mulai Materi 1: kehamilan normal dan risiko, Materi 2: Persalinan normal dan risiko, Materi 3: Persalinan aman dan nyaman dan Materi 4: Peran kader dalam persiapan persalinan, Masing-masing materi terdiri dari 10 pertanyaan sederhana, item penilaian dari post test ini terdiri dari 3 kategori yaitu Baik, Cukup dan Kurang, hasil penilaian Baik jika peserta dapat menjawab 4-5 pertanyaan, hasil penilaian Cukup jika peserta dapat menjawab 3-2 pertanyaan, dan hasil penilaian Kurang jika peserta dapat menjawab 1 pertanyaan atau tidak mampu menjawab pertanyaan dengan baik, kegiatan ini diikuti oleh 25 Kader kesehatan di desa hajimena,

Hasil post Test yang didapatkan pada Materi 1: tentang kehamilan normal dan risiko, didapatkan pengetahuan kader Baik terdapat 25 (100\%), Pada hasil post test Materi 2 : tentang Persalinan normal, didapatkan pengetahuan kader Baik terdapat 25 (100\%), hasil post test Materi 3: tentang Persalinan aman dan nyaman didapatkan pengetahuan kader Baik terdapat $25(100 \%)$ Sementara 
pada hasil post test materi 4: yaitu tentang Peran kader dalam persiapan persalinan didapatkan pengetahuan kader Baik terdapat 25 (25\%),

Hasil evaluasi tersebut menunjukkan peningkatan dari sebelum diberikan materi oleh tim pengabmas dan sesudah diberikan materi oleh tim, dan hal ini menunjukkan peran kader dalam persiapan persalinan sangat mendukung tercapainya perawatan antenatal terhadap ibu hamil dalam mempersiapkan persalinannya untuk mencegah terjadinya resiko pada ibu hamil sebelum dan sesudah persalinan.

\section{Luaran}

Kegiatan Pengabmas PKM selain hasil yang didapat sesuai dengan indicator keberhasilan pengabmas ini terdapat juga luaran yang dicapai, luaran yang dicapai ini antara lain:

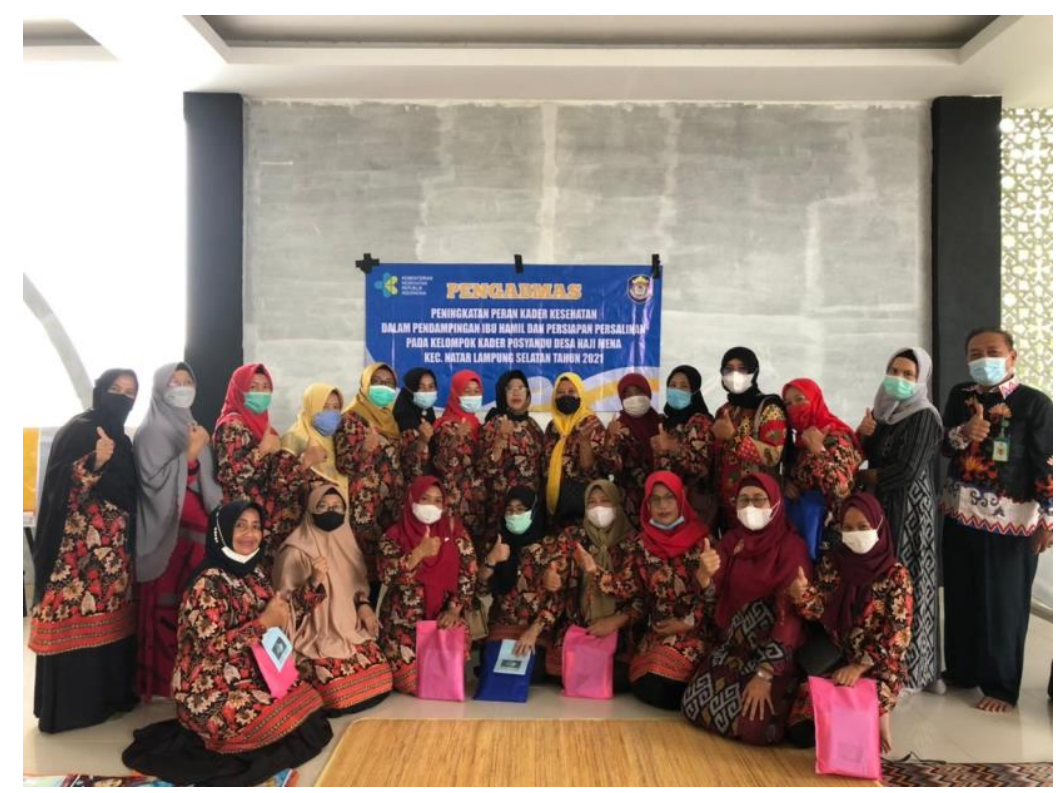

Gambar 4 Pembagian Luaran Pengabmas

1. Buku Panduan Peran Kader dalam Persiapan Persalinan

Panduan ini dibuat oleh tim pengabmas dan memberikan manfaat bagi pembaca, baik bagi Umum, dosen, mahasiswa dan khususnya untuk ibu hamil dan kader untuk mempersiapakn persalinan dan kehamilan dengan baik serta pentingnya peran kader kesehatan dalam pendampingan ibu selama kehamilan. Selain di buat panduan ini di HAKI kan oleh tim pengabmas.

2. Leaflet Panduan Peran Kader dalam Persiapan Persalinan

Tim pengabmas selain membuat panduan juga membuat media penyuluhan berupa Leaflet, leaflet ini sudah diberikan kepada masyarakat di wilayah kerja puskesmas Hajimena dan Kader kesehatan, yang akan memberikan manfaat khusunya bagi masyarakat dan ibu hamil

3. Jurnal Pengabmas

Kegiatan pengabmas ini selanjutnya diadakan seminar hasil dari kegiatan pengabdian masyarakat yang telah dilakukan oleh tim, selain hasil yang didapat dan laporan yang telah dibuat oleh tim, dibuat jurnal pengabmas dan dipublikasikan pada kegiatan seminar hasil nanti, jurnal 
ini akan dipublikasi pada Jurnal Kreativitas Pengabdian Kepada Masyarakat (PKM) penerbit Universitas Malahayati yang telah terakreditasi SINTA 4.

\section{KESIMPULAN}

Simpulan yang didapat dari hasil kegiatan Pengabmas PKM oleh Tim Pengabmas PKM dosen Poltekkes Tanjungkarang kepada Kader kesehatan yang berada di wilayah kerja puskesmas Hajimena antara lain:

a. Hasil Pre Test yang didapatkan pada Materi 1: tentang kehamilan normal dan risiko, didapatkan pengetahuan kader Baik terdapat 2 (8\%), pengetahuan kader Cukup terdapat 10 (40\%) dan pengetahuan kader Kurang terdapat $13(52 \%)$, hasil pre test Materi 2 : tentang Persalinan normal, didapatkan pengetahuan kader Cukup terdapat 15 (60\%) dan pengetahuan kader Kurang terdapat 10 (40\%), sedangkan hasil pre test Materi 3: tentang Persalinan aman dan nyaman didapatkan pengetahuan kader Cukup terdapat 12 (48\%) dan pengetahuan kader Kurang terdapat 13 (52\%), Sementara pada hasil Pre test materi 4: yaitu tentang Peran kader dalam persiapan persalinan didapatkan pengetahuan kader Baik terdapat 2 (8\%), pengetahuan kader Cukup terdapat 10 (40\%) dan pengetahuan kader Kurang terdapat 13 (52\%).

b. Kegiatan penyampaian materi berjalan dengan baik dan lancar memberikan dampak positif bagi kader kesehatan, dan memberikan pengetahuan kepada kader mengenai kehamilan, persalinan, dan apa saja yang harus diedukasikan oleh kader kepada ibu hamil mengenai persiapan persalinan dan pentingnya peran kader dalam mendampingi pesiapan dan persalinan ibu hamil

c. Hasil post Test yang didapatkan pada Materi 1: tentang kehamilan normal dan risiko, didapatkan pengetahuan kader Baik terdapat 25 (100\%), Pada hasil post test Materi 2 : tentang Persalinan normal, didapatkan pengetahuan kader Baik terdapat 25 (100\%), hasil post test Materi 3: tentang Persalinan aman dan nyaman didapatkan pengetahuan kader Baik terdapat 25 (100\%) Sementara pada hasil post test materi 4: yaitu tentang Peran kader dalam persiapan persalinan didapatkan pengetahuan kader Baik terdapat 25 (25\%),

d. Hasil evaluasi Akhir menunjukkan peningkatan dari sebelum diberikan materi oleh tim pengabmas dan sesudah diberikan materi oleh tim, dan hal ini menunjukkan peran kader dalam persiapan persalinan sangat mendukung tercapainya perawatan antenatal terhadap ibu hamil dalam mempersiapkan persalinannya untuk mencegah terjadinya resiko pada ibu hamil sebelum dan sesudah persalinan.

\section{SARAN}

a. Perlu dilakukan sosialisasi secara terus menerus mengenai Peran kader untuk pendampingan ibu hamil dalam persiapan kehamilan dan persalinan, sehingga dengan harapan menurunkan angka kejadian komplikasi kehamilan dan kematian ibu dan bayi .

b. Kegiatan Pengabmas PKM dipandang perlu untuk dilanjutkan dimasa datang hal ini terkait dengan masih banyak kader kesehatan yang belum mengetahui perannya pendampingan ibu hamil dalam persiapan kehamilan dan persalinan. 


\section{DAFTAR PUSTAKA}

Arikunto. (2013). Prosedur Penelitian suatu Pendekatan Praktek.Jakarta : Rineka Cipta. Hal : 151

Buku KIA. (2014). Kemenkes RI

Cahyo K, Rimawati E, Widagdo L, Solikha DA. (2008). Kajian adaptasi sosial psikologis pada ibu setelah melahirkan (post partum) di ruang rawat inap RSUD Kota Semarang. Jurnal Promosi Kesehatan Indonesia.

Depkes RI. (2007).Paket pelatihan Kader Kesehatan dan Tokoh Masyarakat dalampengembangan Desa Siaga. Jakarta.

Depkes RI. (2009). Senam Ibu Hamil. Jakarta.

Depkes RI. (2006) . Materi Ajar Penurunan Kematian Ibu Dan Bayi Baru Lahir. Jakarta

Hidayat. (2007). Metode Penelitian Kebidanan Dan Teknik Analisis Data. Jakarta: Salemba Medika

Hidayat. (2009). Metode Penelitian Keperawatan Dan Teknik Analisis Data. Jakarta: Salemba Medika

Https://www.who.int/news-room/fact-sheets/detail/maternal-mortality

Https://www.who.int/news-room/feature-stories/detail/10-ways-to-improvethe-quality-of-care-in-health-facilities

Kemenkes RI. (2014). Pegangan Fasilitator Kelompok Ante Natal . Jakarta

Kemenkes RI. (2014). Pedoman Pelaksanaan Kelompok Ante Natal . Jakarta.

Kesehatan. PT Raja Grafindo Persada. Jakarta.

Muhammad A. Mikrajab et.al. (2012). The role of health cadres in applying childbirth planning and complications prevention program for pregnant women at integrated health services post in Mojokerto city, East Java province. Buletin penelian Sistem Kesehatan Vol 15 no 4 Oktober 2012

Nani Khomsah ( 2012 ). Faktor-faktor yang berhubungan dengan peran serta kader posyandu dalam deteksi faktor risiko ibu hamil di wilayah kerja PKM Buayan Kebumen Jawa Tengah, Skripsi FKM UI

Notoatmodjo. (2010). Metode Penelitian Kesehatan. Jakarta: Rineka Cipta.

Nursalam. (2008). Konsep dan Penerapan Metodologi Penelitian IImu Keperawatan. Jakarta: Salemba Medika

Profil Dinas Kesehatan Kabupaten Lombok Barat tahun 2017

Profil Dinas Kesehatan Propinsi Nusa Tenggara Barat tahun 2018.

Profil Kesehatan Indonesia (2017) Kemenkes RI Jakarta 2018

Reni dkk. (2016). “ Upaya Peningkatan Pengetahuan Ibu Hamil Dan Kader Posyandu Balita Tentang Pengenalan Tanda Bahaya Kehamilan Di Kabupaten Banyumas" Jurnal Pengabdian Masyarakat.

Riset Kesehatan Dasar. (2018). Kemenkes RI Jakarta

Saifudin, A. (2010). Sikap Manusia Teori dan Pengukuran, ed. K. .2. Yogyakarta: Pustaka Pelajar.

Sinta, F. (2011). Promosi Kesehatan. Yogyakarta: Graha Ilmu.

Soekidjo, N., Promosi Kesehatan dan Ilmu Perilaku. 2007, Jakarta: PT Rineka Cipta.

Sorongan Lucia. (2013). Pengaruh pelaksanaan kelompok Ante Natal terhadap persiapan persalinan

Wiknjosastro, Hanifa. (2008 ). Ilmu Kebidanan. PT Yayasan Bina Pustaka. Jakarta 